\title{
Membangun Program Komunitas Wirausaha Siswa Melalui Pendidikan Berorientasi Kerja
}

\author{
Syamsuar Abbas, Zelhendri Zen, Reflianto \\ Universitas Negeri Padang \\ syamsuar.unp@fik.unp.ac.id
}

Submitted: $31^{\text {st }}$ July 2019. Revised: $11^{\text {th }}$ October 2019. Accepted: $31^{\text {st }}$ October 2019

\section{Key word:}

Students,

Community

Program;

Students

Entrepreneurship;

work oriented

school

\section{Kata Kunci}

Program

Komunitas;

Kewirausahaan

Siswa; Sekolah

Berorientasi

Kerja

\section{Abstract}

The community services purposes was to establish the work-oriented school community program and prepared the volunteers as trainer for digital design Corel draw and photoshop as well as the training of producing any souvenir made by shellfish shells in order to build a workoriented education program in the Senior high school community and strengthen the students' entrepreneur skills in two State Senior High School 12 and 13 Padang. This Community-Based Research approach involved two state senior high school students in Padang City. The result of the services showed that the program of community-based research plays an important role in realizing the work-oriented education program by strengthening the local industrial contents and extracurricular activities of entrepreneurship training in the schools. It could be seen from the improvement of students' skill in the creative business of digital design and souvenir products made by shellfish as well as increasing student's spirit for directly involving in the activities of entrepreneurship in their school. Follow up these activities should strengthen the cooperation among another school in West Sumatra to have the graduates of ready to work and ready to be entrepreneur indirectly help the government to reduce the educated unemployment in West Sumatra as well.

\section{Abstrak}

Tujuan pengabdian ini adalah untuk membangun program komunitas sekolah berorientasi kerja dan menyiapkan relawan sebagai pelatih untuk pelatihan Digital Desain Corel Draw dan Photoshop serta pelatihan membuat produk souvenir dari kerang-kerangan dalam rangka membangun program pendidikan berorientasi kerja di komunitas siswa sekolah menengah atas dan Negeri 12 dan 13 Padang. Penelitian ini menggunakan pendekatan Penelitian Berbasis Masyarakat yang bekerja sama dengan Universitas Negeri Padang. Hasil pengabdian menunjukkan bahwa program berbasis masyarakat ini memainkan peran penting dalam mewujudkan program pendidikan berorientasi kerja melalui penguatan konten industry lokal dan kegiatan ekstrakurikuler pelatihan kewirausahaan di sekolah. Kegiatan Ini bisa dilihat dari meningkatkan keterampilan siswa dalam bisnis kreatif desain digital dan produk-produk suvenir serta mampu meningkatnya semangat siswa untuk terlibat langsung dalam kegiatan kewirausahaan di sekolah mereka. Tindak lanjut dari kegiatan ini harus memperkuat kerja sama antara sekolah-sekolah SMA lainnya di Sumatra Barat agar lulusan yang 
siap bekerja dan siap menjadi wirausaha muda yang secara tidak langsung juga membantu pemerintah mengurangi pengangguran terdidik di Sumatera Barat.

\section{PENDAHULUAN}

Melihat Laporan Indonesia

Educational Statistical in Brief 2018

Kementrian Pendidikan dan Kebudayaan melaporkan jumlah sekolah setara SD, SMP, SMA dan SMK secara keseluruhan adalah berjumlah 384.269. Dari keseluruhan sekolah umum tersebut berdasarkan Data Badan Pusat Statistik bulan Agustus 2017 menunjukkan tingkat pengangguran lulusan sekolah Menengah Menengah Atas $7.95 \%$, semenara tinkat pengangguran lulusan Sekolah Menengah Kejuruan lebih tinggi lagi mencapai 11.25\%. Data ini menunjukkan angka pengangguran terdidik di Indonesia masih tinggi terutama untuk lulusan dari jenjang pendidikan yang sekolah menengah. (Dkatdata.co.id.Kamis 2 Mei 2019) Disisi lain tersebar informasi makin maraknya tenaga kerja asing yang bekerja di Indonesia menjadi tantangan besar bagi angkatan kerja masyarakat Indonesia lulusan Sekolah Menengah Atas.

Namun demikian, sekolah menengah atas bagi masyarakat Indonesia tetap memiliki daya tarik yang cukup besar. Hal ini dibuktikan dengan terus meningkatkan siswa baru yang masuk ke sekolah menengah atas dari tahun ke tahun dengan rata-rata peningkatan sebesar $4,3 \%$, sehingga berdasarkan data CIDIES, pada tahun 2018 diperkirakan jumlah siswanya mencapai 7,5 juta orang dari sekitar 77 juta jumlah penduduk usia sekolah di Indonesia. Persoalannya adalah, bagaimana mempercepat peningkatkan mutu lulusan sekolah menengah dengan 7,5 juta siswanya tersebut? Peningkatan mutu pendidikan secara merata adalah persoalan mutlak bagi eksistensi sebuah bangsa dengan tanpa membedakan identitas kultural masyarakatnya. Ketertinggalan suatu kelompok masyarakat dari sebuah bangsa pada umumnya terbukti menjadi batu sandungan dan sumber masalah bagi perjalanan bangsa itu sendiri. Atas dasar itulah kita perlu mencontoh Negara seperti Singapura yang berupaya keras meningkatakan mutu madrasah dan lembaga-lembaga pendidikan Umum (Melayu) agar sejajar dengan lembaga pendidikan pada umumnya melalui program Joint Madrasah System (JMS) (Yun-Kyoung Jung, 2012).

Reformasi pendidikan islam juga terjadi di Amerika Serikat yang merubah paradigma lulusan harus unggul dan mampu menjawab pasar. Upaya percepatan peningkatan mutu sekolah pun dilakukan di negeri Paman Sam melalui (negosiasi 
kreatif) dengan pemerintah pusat dan lokal dengan membentuk Islamic Educational community yang membangun kreativitas dan keterampilan kerja pada siswa sekolah (Report of a conference held at the University of Cambridge on 9-10 April 2011 McCarty, Andrew. 2007).

Reformasi pendidikan ini berkembang seiring dengan perkembangan teknologi di era reviolusi industry 4.0 yang telah membawa sistem pendidikan tidak lagi hanya terpusat di sekolah, tetapi juga melibatkan masyarakat industri. Untuk itu diperlukan kterampilan siswa dalam menguasai bidang kerja industry saat ini yang semuanya mengharuskan seseorang menguasai ketermpilan desain grafis digital, pemograman dan kreativitias dalam membuat berbagai produk souvenir dari bahan limbah, salah satunya adalah memanfaatkan limbah kerang-kerangan. Sekolah Memengah Atas saat ini bila ingin membangun lembaga pendidikan yang berkualitas, selain dituntut meningkatkan kualitas pengajaran juga dituntut meningkatkan kualitas keterampilan siswa yang dapat membuka peluang kerja yang lebih luas

Melihat kondisi lulusan SMA saat ini yang banyak menyumbangkan pengangguran, telah menjadi tantangan besar bagi sekolah untuk membenahi kurikulum pendidikan mereka. Laporan
Human Development Index untuk indonesia, dari 121,2 juta angkatan kerja, hanya 114 juta yang diserap sektor kerja. Hal ini menunjukkan kurang lebih 7,2 juta pengangguran terbuka atau mencapai 5,92 persen. Dari jumlah tersebut, kira-kira 6,8 juta adalah lulusan sekolah menegah atas (BPS National 2018). Diperkirakan di tahun 2017 Sumatera Barat akan menyumbang 3900 orang penganggur lulusan setingkat sekolah menengah (BPS Provinsi Sumatera Barat Tahun 2018).

Berdasarkan laporan biro statistik lulusan SMA belum banyak memberikan kontribusi dalam penanggulangan masalah pengangguran di Sumatera Barat. Hingga tahun 2018 tercatat sumbangan pengangguran lulusan SMA sebesar 3900 orang (BPS Provinsi Sumatera Barat Tahun 2018). Untuk mengatasi hal ini perlu adanya suatu program peningkatan sumber daya lulusan SMA berkualitas tidak saja dalam bidang sains, tetapi juga keterampilan berwirausahasa untuk membuka lapangan pekerjaan sendiri.

Mengutip dari beberapa pengabdian masyarakat yang pernah dilakukan di dunia dan melihat kondisi lulusan SMA saat ini, maka kami sebagai masyarakat akademis di Sumatera Barat merasa diundang untuk berperan serta membangun program komunitas wirausaha siswa melalui pendidikan berorientasi kerja yang sangat 
diperlukan siswa untuk memasuki pasar kerja terutama di Sumatera Barat. Sasaran program ini adalah membekali siswa SMA dengan berbagai keterampilan kerja desain grafis digital dan wirausaha industry kreatif souvenir dari kerang-kerangan. Program ini diharapkan dapat membantu pemerintah dalam mengurangi angka pengangguran terdidik di Sumatera Barat.

\section{METODE}

Metode pengabdian kepada masyarakat ini menggunakan pendekatan untuk mengkaji permasalahan dan memperoleh makna yang lebih mendalam menyangkut pelatihan keterampilan digital printing dan kewirausahaan industry kreatif souvenir products kerang-kerangan melaui program komunitas wirausahaan siswa melalui pendidikan ekstrakulikuler di sekolah yang berorientasikan kerja. Kelompok sasaran kegiatan adalah siswa Sekolah Menengah Atas Negeri (SMAN) 12 dan 13 Padang. Setting pengabdian kepada masyarakat dibagi menjadi tiga tahap, yaitu:

1. Pelatihan Industri Kreatif Desain grafis digital (Corel Draw dan Photoshop) dan memberikan pre test dan post test kepada peserta

2. Pelatihan Membuat Souvenir products dari Kerang-Kerangan
3. Tahap Evaluasi program untuk memperbaiki permasalahan teknis yang ditemukan di lapangan untuk mengukur kemajuan program. Instrumen penelitian menggunakan Lembar Observasi, Pedoman Wawancara Dokumentasi dan catatan lapangan.

\section{HASIL}

1. Pelatihan Industri Kreatif Desain grafis digital (Corel Draw dan Photoshop)

Hasil penelitian menunjukkan skor pre test pserta pelatihan Desain grafis digital rata-rata mean 64,40; modus 67,00; median 66,70; dan standar deviasi 8,394. Distribusi frekuensi skor pre-test dapat dilihat pada tabel 1 berikut ini.

Berdasarkan tabel 1 tersebut diketahui bahwa terdapat 2 mahasiswa yang memperoleh skor pre-test tertinggi yaitu 74 dan 13 orang yang mendapatkan nilai dibawah 60. dari 42 orang peserta. Sedangkan nilai post test adalah mean sebesar 82,7; modus sebesar 81,7; skor tengah (median) sebesar 83,3; dan standar deviasi sebesar 7,55. Hasil perhitungan selengkapnya dapat dilihat pada lampiran. 
Tabel 1. Skor Pre-test Kemampuan Awal Desain grafis digital

\begin{tabular}{|c|c|c|c|c|c|}
\hline & $\begin{array}{l}\text { Fre } \\
\text { que } \\
\text { ncy }\end{array}$ & Percent & $\begin{array}{l}\text { Valid } \\
\text { Percent }\end{array}$ & $\begin{array}{l}\text { Cumula } \\
\text { tive } \\
\text { Percent }\end{array}$ \\
\hline \multirow[t]{18}{*}{ Valid } & 45 & 1 & 2.4 & 2.4 & 2.4 \\
\hline & 48 & 1 & 2.4 & 2.4 & 4.8 \\
\hline & 50 & 2 & 4.8 & 4.8 & 9.5 \\
\hline & 52 & 1 & 2.4 & 2.4 & 11.9 \\
\hline & 53 & 2 & 4.8 & 4.8 & 16.7 \\
\hline & 55 & 1 & 2.4 & 2.4 & 19.0 \\
\hline & 58 & 5 & 11.9 & 11.9 & 31.0 \\
\hline & 62 & 1 & 2.4 & 2.4 & 33.3 \\
\hline & 63 & 1 & 2.4 & 2.4 & 35.7 \\
\hline & 65 & 3 & 7.1 & 7.1 & 42.9 \\
\hline & 67 & 7 & 16.7 & 16.7 & 59.5 \\
\hline & 68 & 4 & 9.5 & 9.5 & 69.0 \\
\hline & 70 & 4 & 9.5 & 9.5 & 78.6 \\
\hline & 72 & 5 & 11.9 & 11.9 & 90.5 \\
\hline & 75 & 1 & 2.4 & 2.4 & 92.9 \\
\hline & 77 & 1 & 2.4 & 2.4 & 95.2 \\
\hline & 78 & 2 & 4.8 & 4.8 & 100.0 \\
\hline & Total & 42 & 100.0 & 100.0 & \\
\hline
\end{tabular}

Distribusi frekuensi skor post-test kemampuan awal peserta mengalami peningkatan setelah mengikuti pelatihan seperti yang dapat dilihat pada tabel 2 berikut ini.

Tabel 2 Frekuensi Skor Post-test Kemampuan Desain grafis digital

\section{Skor Post Tes}

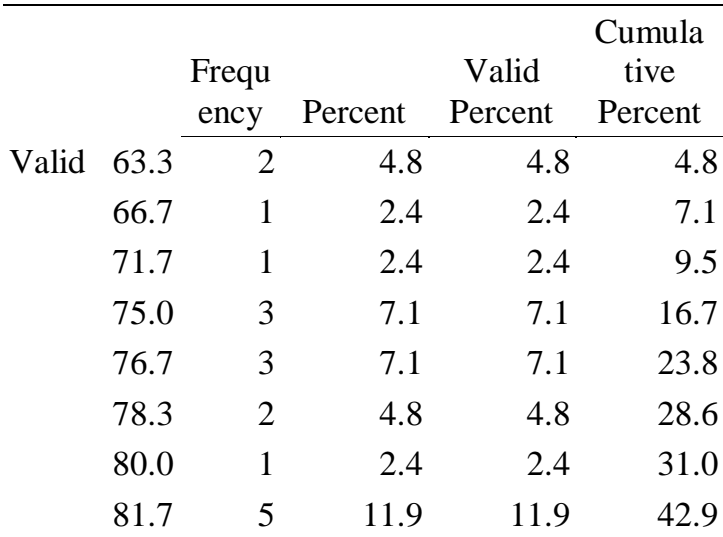

\begin{tabular}{lrrrr}
83.3 & 4 & 9.5 & 9.5 & 52.4 \\
85.0 & 3 & 7.1 & 7.1 & 59.5 \\
86.7 & 5 & 11.9 & 11.9 & 71.4 \\
88.3 & 3 & 7.1 & 7.1 & 78.6 \\
90.0 & 5 & 11.9 & 11.9 & 90.5 \\
91.7 & 1 & 2.4 & 2.4 & 92.9 \\
93.3 & 3 & 7.1 & 7.1 & 100.0 \\
Tot & 42 & 100.0 & 100.0 & \\
al & & & & \\
\hline
\end{tabular}

Berdasarkan tabel tersebut, maka dapat diketahui bahwa terdapat 27 orang peserta yang memiliki nilai diatas 80 dan 15 orang yang mendapatkan niai dalam rentang 60-80 dari 42 peserta pelatihan. Perbandingan nilai pre test dan post test siswa untuk Digital Design di SMAN 12 Kota Padang adalah :

Tabel 3 Skor Pre-test dan Post-test Kemampuan Digital Design Peserta

\begin{tabular}{clcc}
\hline No & Data Statistik & $\begin{array}{c}\text { Pre- } \\
\text { test }\end{array}$ & Post-test \\
\hline 1 & N & 42 & 42 \\
2 & Skor Tertinggi & 78 & 93.3 \\
3 & Skor Terendah & 45 & 63.3 \\
4 & Mean & 64.4 & 82.7 \\
5 & Mode & 67.0 & 81.7 \\
6 & Median & 66.7 & 83.3 \\
7 & Standar Deviasi & 8.394 & 7.558 \\
\hline
\end{tabular}

Dari tabel 3 di atas, kemudian dapat dibandingkan antara skor pre-test dan posttest kemampuan desain grafis digital Peserta Pelatihan di SMAN 12 Padang. Pada kelompok pre test skor tertinggi sebesar 78 dan skor terendah sebesar 45 . Peningkatan terjadi pada post-test dengan skor tertinggi 93.3 dan skor terendah 63.3.. Hal ini menunjukkan adanya peningkatan 
skor rata-rata keteramplan desain kreatif siswa menggunakan corel draw antara sebelum mengikuti pelatihan dengan setelah mengikuti pelatihan desain grafis digital di SMAN 12 Padang. Hal ini menunjukkan ada perbedaan nilai rata-rata yang cukup signifikan antara pre test dengan post-test menggunakan uji independent t-test di bawah ini.

Hasil uji t-test yang dilakukan didapatkan hasil keterampilan desain grafis digital siswa SMAN 12 Padang mengalami peningkatan signfikan dimana adanya perbedaan kemampuan membuat berbagai desain produk digital menggunakan corel draw dan photoshop dengan lebih baik. Peningkatan terjadi antara sebelum dan sesudah mengikuti pelaithan. Seperti yang terlihat pada table di bawah.

Tabel 4 Uji Hipotesis Independent t Test

\begin{tabular}{|c|c|c|c|}
\hline \multicolumn{4}{|c|}{ Independent Samples Test } \\
\hline & \multicolumn{3}{|c|}{ t-test for Equality of Means } \\
\hline & $\begin{array}{l}\text { Sig. (2- } \\
\text { tailed) }\end{array}$ & $\begin{array}{c}\text { Mean } \\
\text { Difference }\end{array}$ & $\begin{array}{l}\text { Std. Error } \\
\text { Difference }\end{array}$ \\
\hline $\begin{array}{c}\text { Skor Equal } \\
\text { variances } \\
\text { assumed }\end{array}$ & .000 & -18.295 & 1.742 \\
\hline $\begin{array}{l}\text { Equal } \\
\text { variances } \\
\text { not } \\
\text { assumed }\end{array}$ & .000 & -18.295 & 1.742 \\
\hline
\end{tabular}

Hasil output SPSS 17.0 menunjukkan taraf signifikansi $0,000<$ 0,05 , yang artinya terdapat perbedaan keteramplan membuat desain grafis digital menggunakan coreldraw dan photoshop siswa SMAN 12 Padang antara sebelum mengikuti pelatihan dengan setelah mengikuti pelatihan yang diikuti oleh 42 orang ssiwa SMAN 12 Padang yang terbukti mampu meningkatkan kemapuan kecakapan desain grafis digital siswa dalam menggunakan program coreldraw dan photoshop.

\section{Pelatihan Membuat Souvenir products dari Kerang-Kerangan}

Hasil Pre Test kemampuan siswa membuat berbagai jenis souvenir products dari kerang-kerangan diperoleh rata-rata (mean) sebesar 68,60; modus sebesar 58,; skor tengah (median) sebesar 69,15; dan standar deviasi sebesar 9,035. Distribusi frekuensi skor pre-test peserta pelatihan di SMAN 13 Padang untuk kegiatan pelatihan membuat souvenir products dari kerangankerangan dapat dilihat pada tabel 5.

Berdasarkan tabel tersebut diketahui bahwa mahasiswa ada 6 peserta yang mendapatkan nilai $<60$ dan 3 orang yang mendapatkan nilai dalam rentang > 79 sebagian besar 11 peserta memiliki rentang nilai berkisar diatas 60-79. Hasil postes kemampuan siswa membuat aneka souvenir products dari kerang-kerangan didapat mean sebesar 85,17; modus sebesar 87,00; skor tengah (median) sebesar 86,70; dan standar deviasi sebesar 4,978. 
Tabel 5. Skor Pre-test Kemampuan Siswa Membuat Aneka Souvenir products dari Kerang-Kerangan

\begin{tabular}{|c|c|c|c|c|c|}
\hline & & & Pre Test & & \\
\hline & & $\begin{array}{c}\text { Frequ } \\
\text { ency }\end{array}$ & Percent & $\begin{array}{c}\text { Valid } \\
\text { Percent }\end{array}$ & $\begin{array}{l}\text { Cumula } \\
\text { tive } \\
\text { Percent }\end{array}$ \\
\hline Valid & 53 & 1 & 5.0 & 5.0 & 5.0 \\
\hline & 55 & 1 & 5.0 & 5.0 & 10.0 \\
\hline & 58 & 3 & 15.0 & 15.0 & 25.0 \\
\hline & 60 & 1 & 5.0 & 5.0 & 30.0 \\
\hline & 67 & 2 & 10.0 & 10.0 & 40.0 \\
\hline & 68 & 2 & 10.0 & 10.0 & 50.0 \\
\hline & 70 & 3 & 15.0 & 15.0 & 65.0 \\
\hline & 73 & 1 & 5.0 & 5.0 & 70.0 \\
\hline & 77 & 2 & 10.0 & 10.0 & 80.0 \\
\hline & 78 & 1 & 5.0 & 5.0 & 85.0 \\
\hline & 81 & 2 & 10.0 & 10.0 & 95.0 \\
\hline & 82 & 1 & 5.0 & 5.0 & 100.0 \\
\hline & $\begin{array}{l}\text { Tot } \\
\text { al }\end{array}$ & 20 & 100.0 & 100.0 & \\
\hline
\end{tabular}

Distribusi frekuensi skor post-test kemampuan awal membuat aneka produk souvenir products dari kerang-kerangan pada peserta pelatihan di SMAN 13 Padang setelah mengikuti pelatihan dapat dilihat pada tabel 6 berikut ini.

Tabel 6. Skor Post-test Kemampuan Membuat Aneka Souvenir products dari Kerang-Kerangan

\begin{tabular}{|c|c|c|c|c|c|}
\hline \multicolumn{6}{|c|}{ Post Test } \\
\hline & & $\begin{array}{c}\text { Freq } \\
\text { uency }\end{array}$ & Percent & $\begin{array}{c}\text { Valid } \\
\text { Percent }\end{array}$ & $\begin{array}{l}\text { Cumula } \\
\text { tive } \\
\text { Percent }\end{array}$ \\
\hline \multirow[t]{6}{*}{ Valid } & 72 & 1 & 5.0 & 5.0 & 5.0 \\
\hline & 77 & 1 & 5.0 & 5.0 & 10.0 \\
\hline & 78 & 1 & 5.0 & 5.0 & 15.0 \\
\hline & 82 & 1 & 5.0 & 5.0 & 20.0 \\
\hline & 83 & 3 & 15.0 & 15.0 & 35.0 \\
\hline & 85 & 1 & 5.0 & 5.0 & 40.0 \\
\hline
\end{tabular}

\begin{tabular}{lrrrr}
87 & 5 & 25.0 & 25.0 & 65.0 \\
88 & 2 & 10.0 & 10.0 & 75.0 \\
90 & 5 & 25.0 & 25.0 & 100.0 \\
Tot & 20 & 100.0 & 100.0 & \\
al & & & & \\
\hline
\end{tabular}

Berdasarkan tabel tersebut, maka dapat diketahui bahwa tidak satupun peserta yang memiliki nilai rentang dibawah 60, dan hanya 3 orang yang memiliki nilai rentang di atas 60-80. Mayoritas peserta atau 17 orang mendapatkan nilai diatas 80 .

Perbandingan skor pre-test dan post-test kemampuan awal siswa dalam membuat aneka souvenir products dari kerang-kerangan di SMAN 13 Padang dalam program ini adalah

Tabel 7 Perbandingan Pre-test dan PostTest Peserta Pelatihan

\begin{tabular}{clcc}
\hline No & Data Statistik & Pre-test & Post-test \\
\hline 1 & N & 20 & 20 \\
2 & Skor Tertinggi & 82 & 90 \\
3 & Skor Terendah & 53 & 72 \\
4 & Mean & 68.60 & 85.17 \\
5 & Mode & 58.00 & 87.00 \\
6 & Median & 69.15 & 86.70 \\
7 & Standar Deviasi & 9.035 & 4.978 \\
\hline
\end{tabular}

Dari tabel 7 di atas, kemudian dapat dibandingkan antara skor pre-test dan posttest kemampuan membuat aneka produk souvenir products dari kerang-kerangan. Hasil memeperlihatkan bahwa skor pre test tertinggi sebesar 82 dan terendah sebesar 53. Peningkatan terjadi pada post-test dengan skor tertinggi 90 dan skor terendah 72. Hal ini menunjukkan adanya 
peningkatan skor rata-rata keterampilan siswa dalam membuat aneka produk souvenir products yang dirangkai dari kerang-kerangan antara sebelum mengikuti pelatihan dengan setelah mengikuti pelatihan. Hal ini menunjukkan ada perbedaan nilai rata-rata yang cukup signifikan antara pre test dengan post-test. Secara inferensial perbandingan ini diuji menggunakan uji independen test.

Tabel 8 Uji Hipotesis Independent t Test

\begin{tabular}{|c|c|c|c|c|}
\hline \multicolumn{5}{|c|}{ Independent Samples Test } \\
\hline & & \multicolumn{3}{|c|}{$\begin{array}{l}\text { t-test for Equality of } \\
\text { Means }\end{array}$} \\
\hline \multirow{3}{*}{ Skor } & & $\begin{array}{l}\text { Sig. }(2- \\
\text { tailed })\end{array}$ & $\begin{array}{c}\text { Mean } \\
\text { Differe } \\
\text { nce }\end{array}$ & $\begin{array}{c}\text { Std. } \\
\text { Error } \\
\text { Differe } \\
\text { nce }\end{array}$ \\
\hline & $\begin{array}{l}\text { Equal variances } \\
\text { assumed }\end{array}$ & .000 & 16.575 & 2.307 \\
\hline & $\begin{array}{l}\text { Equal variances } \\
\text { not assumed }\end{array}$ & .000 & 16.575 & 2.307 \\
\hline
\end{tabular}

Hasil uiji independent test menunjukkan taraf signifikansi 0,000< 0,05 , yang artinya terdapat perbedaan kemampuan penguasaan program SPSS untuk pengolahan data berbagai jenis peneltian kuantitatif antara skor peserta sebelum mengikuti pelatihan membuat produk souvenir dari kerang-kerangan dengan setelah mengikuti pelatihan bagi 20 orang peserta pelatihan yang ikut di SMAN 13 Padang telah mampu meningkatkan kemapuan kecakapan hidup dalam membuat aneka souvenir dari kerang-kerangan.

Berdasarkan hasil uji normalitasi data yang terlihat penyebaran data sudah normal, maka untuk melihat apakah terdapat hubungan peningkatan kecakapan membuat aneka produk souvenir dari kerang-kerangan oleh siswa SMAN 13 Padang. Hasil uji independent t-test didapatkan adanya perbedaan signfikan antara skor pre test dan post test kecakapan siswa dalam membuat aneka produk souvenir yang terbuat dari kerangkerangan.

\section{PEMBAHASAN}

Pelatihan desain grafis digital dan keterampilan membuat aneka produk souvenir dari kerang-kerangan yang digagas oleh Universitas Negeri Padang untuk siswa sekolah menengah atas dalam rangka menyiapkan lulusan SMA yang siap pakai dan siap kerja dan sekaligus menurunkan angka pengangguran tamatan SMA di Sumatera Barat dengan membentuk komunitas kewirausahaan siswa melalui pendidikan berorientasi kerja dalam kurikulum ekstrakurikuler sekolah. Sekolah yang menjadi dampingan dalam kegiatan ini adalah SMAN 12 dan 13 Padang.

Lulusan SMA hendaknya juga harus siap merubah dirinya dengan we 
serve the real world, artinya apa yang dikeluarkan oleh lembaga pendidikan dapat dilayani oleh dunia kerja, begitu pula sebaliknya apa yang dunginkan dunia kerja dapat dilayani oleh lulusan lembaga pendidikan. Beberapa masukan terhadap kebijakan pemerintah maupun penyelenggara program studi agar cepat berbenah adalah (Djojonegoro, 2003, Suyono, 2003, Tampubolon, 2004): Pembelajaran yang mengakui keahlian yang diperoleh dari manapun. Hal ini dapat dijabarkan sebagai berikut salah satunya melalui Supply driven ke demand driven, dan gabungan model industrial based program ke model kompetensi.

Sejalan dengan perubahan dari supply driven ke demand driven, dari model pengajaran mata pelajaran umum ke program berbasis kompetensi, diperlukan adanya keluwesan yang memungkinkan adanya pelaksanaan praktek kerja industri, dan pelaksanaan prinsip multi entry multi exit.

Prinsip ini memungkinkan siswa sekolah menengah yang telah memiliki sejumlah satuan kemampuan tertentu (karena program pengajarannya berbasis kompetensi), mendapatkan kesempatan kerja di dunia kerja, maka siswa tersebut memungkinkan semakin terampil setelah tamat sekolah, dan dunia industri bisa menerima mereka bekerja dalam dunia kerja industri atau bahkan mereka bisa membuka usaha sendiri menjadi wirausahawan mandiri. keahlian yang diperoleh siswa dari pembelajaran keahlian dengan model yang bersangkutan dari pengalaman kerjanya, maka hal ini supply driven ke demand driven inilah yang mendorong akademisi Universitas Negeri Padang membangun program komunitas wirausahaan siswa melalui pendidikan berorientasi kerja (life skill) yang diburtuhkan dunia industri saat ini seperti keterampilan desain grafis digital dan keterampilan memproduksi aneka sourvenir dari yang terbuat dari kerangkerangan. Tujuan kegiatan ini yang paling utama adalah menyiapkan usahawan muda untuk membuka usaha digital industri dan sourvenir melalui pembentukan program komunitas wirausahaan siswa antar sekolah di Kota Padang, Sumatera Barat. Aniversitas Negeri padang sebagai mitra pendamping memberikan pelatihan desain grafis digital (coreldraw dan photoshop) serta pelatihan membuat aneka souvenir dari kerang-kerangan sebagai produksi cenramata yang banyak diminati wisatawan baik wisatawan domestik maupun wisawatan mancanegara. Keterampilan desain grafis digital dan wirausaha souvenir ini bisa menghantarkan lulusan sekolah menengah atas mendapatkan pekerjaan dengan mudah di dunia saat ini 
dan bahkan terbuka peluang besar bagi mereka untuk menjadi usahawan muda setelah lulus SMA nantinya.

Hasil penelitian ini mendukung penelitian yang dilakukan oleh Yayasan Pendidikan Chili dan UNESCO di Chile tahun 2009 dalam membangun modernisasi pendidikan dasar dan menengah dengan melaksanakan pendidikan berorientasikan kerja. Projek ini melibatkan institusi sekolah menengah, mitra industri dan praktisi pendidikan vokasi serta masyarakat (Bulletin The Major Project of Education in Latin America Latin dan Caribean,. UNESCO. 1999). Hasil penelitian melaporkan kegagalan pendidikan di Chili dalam membangun disiplin, etika, kualitas pembelajaran dan pelatihan kerja selama ini disebabkan oleh orientasi pendidikan hanya fokus pada capaian akademik semata. Kegagalan ini setidaknya berimbas pada kualitas lulusan sekolah menengah dalam mendapatkan akses kerja di Chili sebagaimana yang dilapoirkan oleh Global Coompetitiveness Report (1997) dan World Times Information Society Index 1999 yang menempatkan Chili pada rangking ke-41 lulusannya yang diserap sektor kerja jauh dibawah Irlandia, Korea dan Republik Kroasia. Melihat kondisi ini kemudian Fundacion Chile's Education Programme mengusulkan dibangunya pendidikan berorientasi kerja sejak tahun 2009.

Untuk mengatasi masalah pengangguran lulusan sekolah menengah atas saat ini maka program ini ikut memberikan pembaharuan sistem pembelajaran yang berkkualitas, tidak saja meningkatkan kompetensi kogntiif, tetapijuga mampu memberikan keterampilan soft skill yang boleh dimiliki siswa sesuai dengan minat dan bakat mereka. Oleh karena itu pendidikan di tingkat SMA perlu mengembangkan kurikulum saat ini dengan dampingan pembelajaran keterampilan yang bisa dimasukkan sebagai pembelajaran ekstrakurikuler bidang kehalian di dalam kurikulum sekolah.

Agar program-program pelatihan keterampilan kerja yang diselenggarakan sekolah dalam kegiatan ekstrakurikuler ini tidak sama dengan yang ada saat ini, tetapi pelaksanaan program pelatihan kerja sebagai mata pelajaran ekstrakulikuler ini harus dibangun secara kolaborasi antara tiap sekolah melalui Joint Schoool Community dimana semua sekolah menengah tergabung dalam kegiatan ini kemudian menyelenggarakan program pelatihan keterampilan siswa pada kegiatna ekstrakurikuler berkerjasama dengan pemerintah daerah, perguruan tinggi, dunia Industri dan projek keterampilan usaha 
kreatif.. Melalui Joint Schoool Community, akan memberikan peluang kepada seluruh siswa SMA sebelum lulus telah memiliki keterampilan dan pengalaman kerja dalam Progam Magang yang digagas bersama Dunia Industri untuk memungkinkan mereka langsung dapat bekerja setelah tampat atau lulus dari sekolahnya.

Hasil program ini menunjukkan bahwa perlunya rereformasi sistem pendidikan yang ada saat ini, tidak saja focus pada teori semata, tetapi juga memberikan keterampilan desain grafis digital dan kemampuan berwirausahaan mandiri kepada siswa seperti yang sudah dilaksanakan di sekolah-sekolah di Amerika Serikat sejak tahun 2017. Sekolah Amerika Serikat sudah membangun paradigma lulusan mereka harus unggul dan mampu menjawab permintaan pasar. Upaya percepatan peningkatan mutu pendidikan pun dilakukan di negeri Paman Sam ini melalui negosiasi kreatif dengan pemerintah pusat dan lokal untuk membentuk Usaha Berbasis Intrelektual di lingkungan Kampus melalui pembangunan kreativitas dan keterampilan kerja Industri Kreatif di kalangan siswa sekolah menengah (Report of a conference held at the University of Cambridge on 9-10 April 2017). .

Program Pengembangan Unit Produk Intelektual Kampus yang digagas
UNP pada intinya adalah memberikan pendampingan program pelatihan keterampilan kepada siswa sekolah menengah atas. Melalui kerja sama dengan berbagai stakeholder dan kemitraan usaha digital printing, advertising dan industry kreatif souvenir yang memanfaatkan bahan laut (kerang-kerangan) menjadi nilai jual tinggi. Program ini telah menghasilkan beberapa siswa yang sudah terlibat dalam usaha digital printing dan usaha souvenir yang terbuat dari kerang-kerangan yang dijual di tempat-tempat wisata baik di Padang maupun di Padang Pariaman sebagai pangsa pasarnya. Program ini setidaknya telah mengurangi tingkat pengangguran lulusan SMA di Sumatera Barat.

Program ini berupaya membangun usaha mandiri di kalangan siswa SMA, dengan menjadi penguasaha muda ketika sudah lulus dari pendidikan. Artinya pendidikan Sekolah Menengah akan memberikan dua program yaitu pendidikan kongitif berbasis kuriklum wajib nasional, dan pendidikan keterampilan berbasis pada kegiatan ekstrakurikuler sekolah yang deprogram menjadi pendiidkan pelatihan dalam satu komunitas sekolah yang saya sebut dengan Joint School Community. Artinya dari program ekstrakurikuler ini, siswa sekolah menegah selain mendapatkan ilmu dan wawasan kognitif di 
kelas, juga mendapatkan keterampilan kerja sesuai dengan yang diminati dan berpeluang juga menjadi penguasaha mandiri sesuai dengan minat dan bakat yang dibangun dalam kebijakan Joint School Community bersama pemerintah daerah, mitra swasta, perguruan tinggi dan masyarakat. Kehadiran program ini juga berdampak positif bagi upaya Universitas Negeri Padang meningkatkan keterampilan lulusan SMA di Kota Padang dalam mengatasi banyaknya tenaga kerja asing (TKA) yang masuk ke Indonesia. Setidaknya upaya meningkatkan kualitas pendidikan dan membekali siswa SMA dengan keterampilan desain grafis digital yang dibutuhkan dalam semua lini usaha saat ini dan keterampilan memproduksi berbagai souvenir yang terbuat dari kerangkerangan dapat menjadi binaan untuk menguatkan kurikulum ekstrakurikuler pendidikan di SMA, terutama di Kota Padang, Sumatera Barat. Dengan demikian persaingan antara lulusan SMA dalam negeri tidak akan kalah bersaing head to head dengan lulusan asing,

Rekomendasi hasil pengabdian kepada masyarakat ini adalah pentingnya memberikan penguatan keterampilan khusus oleh Universitas bekerja sama dengan Lembaga Pendidikan Menengah untuk melaksanakan program pembelajaran dan pelatihan terpadu dalam unit ekstrakurikluer program Joint School Community, artinya peran Sekolah Menengah harus melibatkan peran aktif semua lapisan masyarakat untuk mendapatkan lulusan sekolah yang berkualitas, siap kerja dan siap menjadi usahawan baru dengan keterampilan yang sudah dibekali di sekolah melalui program komunitas kewirausahaan siswa di Kota Padang.

Terkait dengan mengatasi pengangguran melalui program ini, maka strategi khusus yang telah dilaksanakan untuk mencapai hal tersebut selama pendampingan di sekolah adalah:

1. Meningkatkan kualitas pembelajaran agar siswa memperoleh keterampilan yang sesuai dengan kebutuhan dunia industry saat ini.

2. Menerapkan strategi kompensasi kepada anak-anak miskin untuk mengurangi ketimpangan akses ke pendidikan yang berkualitas di daerah secara sistematik, sehingga mewujudkan masyarakat yang terampil, sejahtera, adil, dan harmonis,

3. Memperkuat pelatihan vokasi dan life skill di semua tingkat. Ini dilakukan untuk mengembangkan angkatan kerja yang fleksibel dan terlatih dengan atribut personal, keterampilan dasar, dan kompetensi TIK. 
4. Meningkatkan Sumber Daya Manusia (Guru) dan membangun pola pikir guru dan tenaga pendidik yang berorientasi pada peningkatan kualitas pendidikan yang kreatif dan berkesinambungan.

5. Mewujudkan program pendidikan pemeritah yang terintegrasi dengan membentuk Sistem manajemen pendidikan yang terintegrasi pula dengan tujuan dapat peningkatan capaian pendidikan yang berkualitas, terampil, dan siap kerja setelah lulus.

6. Merintis kemitraan baru dengan penyelenggara pendidikan, baik perusahaan publik maupun swasta, Dunia Indsutri dan Usaha Kreatif lainnya untuk meningkatkan kualitas pendidikan melalui kinerja berbasis pembiayaan dan akuntabilitas yang lebih baik sehingga menghaislkan lulusan yang siap kerja dan siap menajdi penguasaha baru.

Dari penjelasan diatas jelas bahwa kunci dalam membangun sekolah berkualitas di SMA adalah bergantung pada kemauan dan kemampuan kepala sekolah sebagai pelaksana manajemen pendidikan untuk melakukan pembaharuan dalam berbagai aspek kegiatan pendidikan di tingkat sekolah secara cepat dan tepat. Untuk menjadikan SMA berkualitas, maka kepala sekolah dituntut harus mampu menciptakan pembaharuan sesuai dengan tuntutan era globalisasi dan revolusi industry 4.0 saat ini dimana manajemen pendidikan sudah harus terintegrasi berbasis teknologi internet (IoT). Dengan cara ini sekolahnya mampu menghasilkan lulusan yang dapat menguasai IoT dengan baik untuk memenuhi permintaan tenaga kerja sektor industry saat ini..

Lompatan sistem manajemen yang dilakukan kepala sekolah dapat dianalogikan dengan teori relativitas Albert Einstein (1905), yang mengatakan bahwa setiap masa benda jika dilakukan perubahan dengan kecepatan tinggi, maka akan menghasilkan energi yang sangat besar. Dalam rumus tersebut kecepatan melakukan pembaharuan manajemen pendidikan SMA menuju pada manajemen pendidikan terintegrasi internet (IoT) menjadi kunci utama bila ingin menghasilan pendidikan SMA yang berkualitas

Hasil pengabdian menunjukkan, pembaharuan manajemen pendidikan SMA menjadi sekolah yang berkualitas sangat tergantung pada kinerja kepala sekolah. SMA berkualtas dituntut mampu membangun dan mengembangkan model manajemen pendidikan aktual yang dapat digunakan dalam memecahkan masalahmasalah bidangpendidikan menengah. Tindakan ini dapat dilakukan oleh Kepala SMA melaui pembaharuan model 
pembelajaran yang berorientasi pada peningkatan mutu Pendidikan Menengah dengan cara:

1) Merumuskan visi dan misi yang menjadi keunggulan SMA berbasis pendidikan nasional;

2) Memperhatikan kebutuhan warga sekolah yiatu guru, siswa, orangtua, komite sekolah, dan masyarakat sekitar SMA;

3) Mengoptimalisasikan peran warga sekolah dalam rangka mempercepat pembaharuan dan pengembangan SMA menuju sekolah berkualits;

4) Mampu menciptakan keterpaduan antara SMA dengan masyarakat sekitar;

5) Menciptakan komunikasi yang terbuka dan sinergis di antara warga sekolah;

6) Mampu membaca dan memprediksi kebutuhan ICT dalam pembaharuan SMA berkulatas dengan manajemen pendidikan berbasis IoT;

7) Mampu membaca kebutuhan stakeholder dan mampu menciptakan kualitas PBM dengan memperdayakan sumber daya yang ada mampu menghasilkan lulusan yang relevan sesuai dengan kebutuhan stakeholder;

8) Mampu melakukan perubahan dengan sangat cepat untuk menciptakan pembaharuan SMA menjadi sekolah berkualtias sehingga dapat mengejar ketertinggalan dengan kemajuan dunia industri;

9) Mampu mengambil keputusan dengan cepat dan tepat secara bersama (melibatkan warga sekolah) dalam mengatasi masalah-masalah yang ada;

10) Mengimplementasikan transparansi dalam berbagai aspek termasuk bidang keuangan dengan mengacu pada aturan-aturan yang berlaku;

11) Mewujudkan akuntabilitas lembaga (SMA) sebagai bentuk tanggung jawab terhadap masyarakat;

12) Mampu memotivasi dan berperan sebagai fasilitator dalam rangka menumbuhkan daya inovasi dan kreativitas warga sekolah;

13) Memperhatikan nilai-nilai agama dan budaya bangsa Indonesia sebagai fungsi kontrol dalam melakukan pembaharuan untuk pengembangan SMA;

14) Mampu mengembangkan sekolahnya dalam rangka globalisasi.

Dalam membangun sekolah yang berkuallitas dan efektif maka praktisi manajemen sekolah dalam hal ini kepala sekolah dan guru-guru harus :

1. Kepala sekolah dan guru-guru harus memiliki komitment dan perhatian yang tinggi terhadap perbaikan mutu pengajran 
2. Guru-guru harus memiliki harapan yang tinggi untuk mendukung pencapaian prestasi siswa

3. Kepala sekolah dan guru-guru harus mampu memganbun Iklim sekolah yang ramah, sejuk dan kondusif tanpa ada tekanan dalam sebuah proses pengajaran.

4. Sekolah yang bekualitas harus mempunyai pemahaman yang luas tentang fokus pengajaran dan mengusahakan keefektifan sekolah dengan mendayagunakan seluruh sumber daya sekolah untuk mencapai tujuan secara maksimal

5. Sekolah yang berkualitas harus mamu membangun dan mengembangkan manajemen pendidikan yang berkemajuan dan terintegrasi secara internet (IoT) seluruh proses kegiatan pendidikan mulai dari perencanaan, pelaksanaan dan evaluasi pengajaran.

Pada akhirnya untuk mewujudkan SMA berkualitas di atas maka Kepala Sekolah ditutnut untuk segera membangun Organisasi Sekolah Baru (newly developed). Tujuan membangun organisasi Sekolah Baru ini adalah agar proses pembaharuan manajemen dapat dilaksanakan dengan cepat dan efektf, dan bukan hanya baru dilihat dari segi sarana dan prasarana sekolah yang berstandar internasional, tetapi juga baru dari sisi organisasi dan manajemen pada setiap bidang garapan organisasi sekolah. Begitu pula dalam aspek administrasi peserta didik pada SMA berkualitas yang ingin dibangun pun merupakan peserta didik baru yang diterima di kelas I mulai Tahun Ajaran baru. Namun demikian, sekolah ini dapat menerima pindahan dari sekolah lain pada saat memasuki tahun kedua.

\section{SIMPULAN}

Dari hasil penelitian diperoleh bahwa kegiatan membangun program komunitas wirausahaan siswa melalui pendidikan berorientasikan kerja sangat berperan bagi penguatan pelatihan kewirausahaan siswa sekolah menengah atas di Kota Padang. Melalui program ini sekolah dapat kembali melaksanakan pendidikan kewirausahaan sebagai muatan lokal maupun muatan dari kegiatan pendidikan ektrakurikuler seperti pelatihan desain grafis digital menggunakan proram corel draw dan photoshop serta keterampilan membuat aneka souvenir dari kerang-kerangan yang sebelumnya pernah dilaksanakan, namun karena tidak adanya pelatih yang menjadi mitra pendaping yang mau dirtempatkan di sekolah, menyebabkan muatan lokal ini tidak berjalan efektif.

Melalui program komunitas wirausahaan siswa melalui pendidikan 
berorientasikan kerja yang dilaksanakan di SMAN 12 dan 13 Padang telah kembali memasukkan kurikulum pendidikan kewirausahaan ke dalam kegiatan ekstrakurikuler mereka terutama di SMAN 12 Padang yang fokus pada pelatihan desain grafis digital dan SMAN 13 Padang yang fokus pada kegiatan produksi aneka souvenir yang terbuat dari kerang-kerangan untuk dijual di pasar wisata baik wisatawan domestik maupun wisatawan mancanegara yang berkunjung ke Sumatera Barat, khususnya ke Kota Padang dan Pariaman. Kegiatan ini terbukti berhasil membangun program komunitas wirausahaan siswa melalui pendidikan berorientasikan kerja di tingkat sekolah menengah di kota Padang dimana pada kedua sekolah dampingan telah kembali memasukkan kurikulum pembelajaran kewirausahaan industri kreatif kedalam kurikulum muatan lokal dan kegiatna ekstrakulikuler mereka.

Keberhasilan kurikulum muatan lokal ini mampu melahirkan wirausahawan muda yang terampil yang mampu bersaing dalam industri digital dan produk souvenir yang menjadi produk kebanggaan yang mendukung program ekonomi pariwisata di Sumatera Barat.

\section{Ucapan Terima Kasih}

Terima Kasih kepada Universitas Negeri Padang, Lembaga Pendidikan
SMAN 12 dan 13 Padang beserta seluruh jajarannya yang telah mendukung Program Pengabdian Kepada Masyarakat ini hingga dapat dilaksanakan dan dibentuknya komunitas Sekolah di Kota Padang.

\section{DAFTAR PUSTAKA}

Badan Pusat Statistik (BPS) Nasional Tahun 2018

Badan Pusat Statistik (BPS) Provinsi Sumatera Barat Tahun 2018

Bulletin The Major Project of Education in Latin America Latin dan Caribean, 1999. UNESCO

Creswell W John. (2014). Research Design, Qualitative, Quantitative and Mixed Methods Approaches (4th ed.). SAGE Publication, Inc.

Dkatdata.co.id.Kamis 2 Mei 2019. Tantangan Pendidikan dan Peluang Kerja

Indonesia Educational Statistical in Brief 2018 Kementrian Pendidikan dan Kebudayaan dan Pendidikan.

Karen Hacker, (2013) Community Based Participatory Research, Institute for Community Health, Cambridge Health Alliance, Harvard Medical School, USA. SAGE Publication, Inc.

Report of a conference held at the University of Cambridge on 9-10 April 2011 McCarty, Andrew. 2007. Mengembangkan kepribadian 
p-ISSN : 2548-8783

e-ISSN : 2548-8791

dengan Berpikir Positif. Romlatul

Hikmah, S.Hum. penerjemah.

Jakarta: Prestasi Pustakarya.

Terjemahan dari: How to positive

thinking. 